Тимофєєв Сергій Павлович кандидат наук з державного управління, доцент кафедри публічного управління та адміністрування Чорноморського національного університету імені Петра Могили, вул. 68 Десантників, 10, м. Миколаїв, 54000, тел.: (0512) 76-71-92, e-mail: stymofeev@gmail.com, https://orcid.org/0000-0002-9223-1468

\title{
ПЕРСПЕКТИВИ ПІДВИЩЕННЯ РІВНЯ ДОВІРИ ДО ОРГАНІВ ПУБЛІЧНОї ВЛАДИ В УКРАЇНІ
}

Анотація. У статті проводиться дослідження механізму формування довіри громадськості до органів публічної влади та встановлюються перспективні напрямки підвищення рівня довіри до влади в Україні в сучасних умовах реформування системи публічного управління. Відмічається, що довіра може виникнути лише на основі спільних цінностей, формування політики держави на основі потреб та викликів суспільства, узгодження інтересів держави і народу. Кожна особа, соціальна група або громадська організація, яка зверталась до того чи іншого органу, або ознайомлена з його діяльність має власний «поріг довіри», після досягнення його довіра втрачається. Встановлено, що рівень недовіри до влади в цілому досить різниться. Якщо до Президента та Уряду більшість респондентів відчуває недовіру, то до місцевого керівництва відношення більше позитивне, очевидно через наближеність та наявність можливостей особистого діалогу. Визначено, що окрім рівня довіри, який можливо виміряти лише за допомого соціологічних опитувань та досліджень громадської думки, варто звернути увагу також і на індекс відкритості бюджету. Зроблено висновок, що невисокий рівень довіри з боку суспільства до органів публічної влади може пояснюватися особливостями реалізації соціального діалогу в сьогоднішніх реаліях, котрий скоріш за все $\epsilon$ ширмою для здійснення цілей, подекуди протилежних соціальному партнерству. В останні кілька років рівень довіри до органів публічної влади і держави в цілому зменшується. Низький рівень довіри до влади, у свою чергу, зовсім не сприяє прийняттю дієвих рішень, оскільки навіть якщо вони будуть доцільні, не сприймання їх громадськістю в кінцевому результаті впливатиме на їх практичне впровадження. На основі проведеного дослідження висловлено низку рекомендацій щодо вдосконалення форм взаємодії між владо та суспільством для підвищення рівня довіри та налагодження діалогу.

Ключові слова: довіра до влади, відкритість та прозорість, публічна інформація, органи публічної влади, громадські організації.

Tymofieiev Serhij Pavlovych Candidate of Sciences in Public Administration, Associate Professor of the Department of Public Management and Administration of the Petro Mohyla Black Sea National University, 68 
Paratroopers St., 10, Mykolaiv, 54000, tel.: (0512) 76-71-92, e-mail: stymofeev@gmail.com, https://orcid.org/0000-0002-9223-1468

\title{
PROSPECTS FOR INCREASING THE LEVEL OF TRUST IN PUBLIC AUTHORITIES IN UKRAINE
}

\begin{abstract}
In the article conducted research the mechanism of forming public confidence in public authorities and identifies promising areas for increasing confidence in government in Ukraine in the current context of public administration reform. It is noted that trust can arise only on the basis of common values, the formation of state policy based on the needs and challenges of society, the coordination of the interests of the state and the people. Every person, social group or public organization that has applied to a particular body, or is familiar with its activities, has its own "threshold of trust", after reaching its trust is lost. It is established that the level of distrust in the government as a whole is quite different. If the majority of respondents distrust the President and the Government, the attitude towards the local leadership is more positive, obviously due to the closeness and the possibility of personal dialogue. It is determined that in addition to the level of trust, which can be measured only with the help of opinion polls and public opinion polls, it is also worth paying attention to the index of budget openness. It is concluded that the low level of public confidence in public authorities can be explained by the peculiarities of the implementation of social dialogue in today's realities, which is likely to be a screen for the realization of goals, sometimes contrary to social partnership. In the last few years, the level of trust in public authorities and the state as a whole has been declining. The low level of trust in the government, in turn, does not contribute to effective decisionmaking at all, because even if they are appropriate, not being perceived by the public will ultimately affect their practical implementation. Based on the research were made a recommendations to improve the forms of interaction between government and society to increase trust and dialogue.
\end{abstract}

Keywords: trust in government, openness and transparency, public information, public authorities, public organizations.

Постановка проблеми. Одним 3 важливих чинників, які сприяють підтримки діяльності держави та iї органів, у формування у масовій свідомості довіри, яка є необхідною для делегування ним повноважень, які, у свою чергу, дозволяють органи публічної влади (далі - ОПВ) реалізовувати владні функції. Адже відповідно до Конституції України, джерелом влади в Україні $\epsilon$ народ, який лише делегує повноваження щодо управління державою органам та посадовим особам, тим самим визнаючи право політичних інститутів ухвалювати обов'язкові рішення, здійснювати дії, необхідні для їх реалізації, й відтак надає владі політичну довіру - один із вкрай важливих для існування демократії факторів.

Довіра до влади підвищує легітимність політичних інститутів, ОПВ, окремо інституту місцевого самоврядування та позитивно впливає на їх 
ефективність. Така актуальність даного питання підвищує необхідність дослідження феномену політичної довіри суспільства. Особливо варто враховувати, що характер взаємостосунків між представниками влади й громадянами може бути різним, а рівень довіри до держави, окремих політиків та органів може постійно змінюватись.

Аналіз останніх досліджень i публікацій. Питання довіри громадськості до органів публічної влади розглядаються як теоретиками, так і практиками публічного управління. Серед них можна виділити наступних:

О. Грибко, І. Куспляк, Т. Куценко, О. Кучабський, С. Погорєлий, Л. Родченко, С. Серьогін тощо. Разом 3 цим прослідковується жорстка потреба у дослідженні проблеми підвищення рівня цієї довіри та перспектив майбутнього розвитку у цьому напрямку.

Мета статті - дослідити механізм формування довіри громадськості до органів публічної влади та встановити перспективні напрямки підвищення рівня довіри до влади в Україні в сучасних умовах реформування системи публічного управління.

Виклад основного матеріалу. Під довірою до ОПВ варто розуміти довіру громадян до представників владних органів, сподівання на допомогу, захист та підтримку в складних життєвих ситуаціях, а головне визнання відповідності даних органів таким очікуванням. Окрім цього, у такої довіри є певний «кредит», наприклад - високий рівень довіри до політиків, народних обранців, Президента, міського голови тощо одразу після виборів або призначення на посаду. Адже, фактично, особа ще не приступила до виконання своїх функціональних обов'язків, проте користується певним рівнем довіри, наданої авансом. Кредит довіри до влади також залежить від характеру реальних взаємодій, які складаються між владою і громадянами.

Довіра як суспільне явище вивчається у таких науках, які філософія, соціологія, психологія. Проблема довіри «займає ключове місце при аналізі поведінки людини в складних ситуаціях взаємодії, наприклад, при вивченні конфліктів, соціальної напруженості в суспільстві. В останньому випадку, одним із найважливіших чинників, що викликає соціальну напруженість, $\epsilon$ саме недовіра до держави, іï органів» [1, с. 62].

Враховуючи це, можна спрогнозувати, яким чином можна побудувати механізми створення та закріплення довіри громадян до влади.

Насамперед, довіра може виникнути лише на основі спільних цінностей, формування політики держави на основі потреб та викликів суспільства, узгодження інтересів держави i народу. У демократичних країнах розвинутою моделлю комунікації між владою та населенням $є$ модель соціального діалогу, що сприяє у збільшенню рівня довіри.

Феномен довіри може бути сформований на спільних між владою та суспільством поглядом на національні інтереси, потреби локальних груп, цілі, що з цього випливають, пріоритети завдань, спільність інтересів, орієнтири та критерії ефективності взаємодії з точки зору взаємних витрат та вигоди [2].

Також слід звернути увагу на поняття «поріг довіри». Ним у соціології 
визначають той момент, з якого довіра переходить у недовіру. Він настає за «накопичувальним ефектом» та залежить від індивідуальних особливостей кожної людини, обставин які їі уточують та загальних настроїв у суспільстві.

Для прикладу, пересічний громадянин з високим рівнем недовіри буде відноситись до міської ради у разі, якщо міський голова на справедливі та цілком раціональні звернення громадян, у тому числі i на пропозиції, реагуватиме лише відписками та відноситиметься до думки громадян поверхово [3]. У такому випадку активний громадянин, який висловлює свою позицію або підтримує інших, з великою вірогідністю буде у майбутньому 3 недовірою відноситись до проектів, пропозицій голови та міської ради, навіть у разі якщо вони будуть виглядати цілком слушними, оскільки за красивими гаслами вбачатиме таке ж намагання знехтувати інтересами суспільства та ввести людей в оману.

Кожна особа, соціальна група або громадська організація (далі - ГО), яка зверталась до того чи іншого органу, або ознайомлена з його діяльність має власний «поріг довіри», після досягнення його довіра втрачається.

Варто зазначити, що зниження рівня довіри не обов'язково викликає негайні політичні наслідники, так як акції протесту, масові заворушення тощо. Втрата довіри до влади має певні етапи розвитку [4, с. 155].

Перш за все, на початковому етапі така втрата викликає, передусім, персональне відчуження від політики. Насамперед, це проявляється у низькій явці на виборів чи референдумах, так як населення не довіряє і не цікавиться політикою. Потім така недовіра може викликати підвищену агресивність, спрямовану на конкретну посадову особу або ОПВ. А вже після досягнення піку соціального напруження у суспільстві, така недовіра може вилитись у складні політичні наслідки. Наприклад, така втрата довіри та соціальна напруга призвели до Революції Гідності.

Так, на нашу думку, дієвим механізмом збереження рівня довіри громадян до ОПВ, є відкритий, чесний, толерантний діалог держави 3 громадянами. Цьому сприятиме загальне формування системи зовнішнього громадського контролю, прийняття прозорих політичних рішень, проведення на постійній основі та за сприяння ОПВ незалежних громадянських експертиз та систематичній підзвітності влади громадськості.

Найвищим рівнем формування довіри між суспільством та ОПВ $є$ побудова партнерських відносин. Так, це передбачатиме об'єднання зусиль влади і громадськості у напрямку пошуку шляхів і ресурсів для вирішення важливих проблем суспільства.

Щодо дослідження рівня довіри до влади, то на нашу думку, одним 3 найавторитетніших у цьому напрямку досліджень $є$ ті, які проводиться спеціалістами центру О. Разумкова.

Варто зазначити, що Український центр економічних та політичних досліджень ім. О. Разумкова $є$ недержавним та має на меті проведення аналітичних досліджень. Центр був заснований у 1994 році та систематично 
здійснює дослідження державної політики у сферах внутрішньої та зовнішньої політики, державного управління, енергетики, соціальної політики, міжнародної та місцевої безпеки, тощо [5].

Дослідження проводяться експертами у різних галузях, а саме центр функціонує на засадах та цінностях демократії та верховенства права; захисту прав і свобод людини; відповідальності держави перед суспільством; ефективної державної політики, активної участі громадян у визначенні основних засад і пріоритетів державної політики.

Останне дослідження рівня довіри до влади центром було проведено у березні 2020 року. У ході дослідження були проаналізовані відповіді на визначені запитування 2000 повнолітніх та дієздатних респондентів у всіх регіонах України, за винятком Криму та окупованих територій Донецької та Луганської областей.

Респонденти відповідали вибірці, яка репрезентує доросле населення країни за основними соціально-демографічними показниками. Теоретична похибка вибірки перевищує $2,3 \%$, тобто висновки даного дослідження $є$ достатньо точними (рис. 1 , рис. 2 , рис. 3 ).

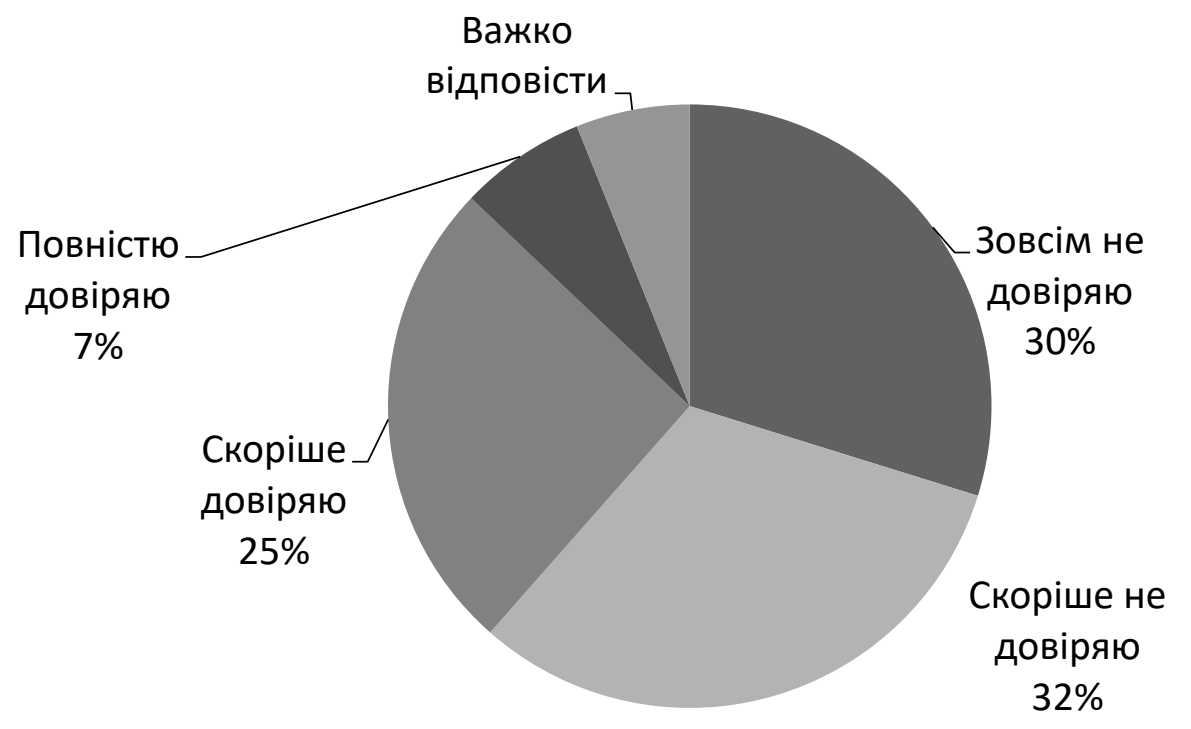

Pис. 1. Відповіді респондентів на запитання щњодо довіри Президенту України 


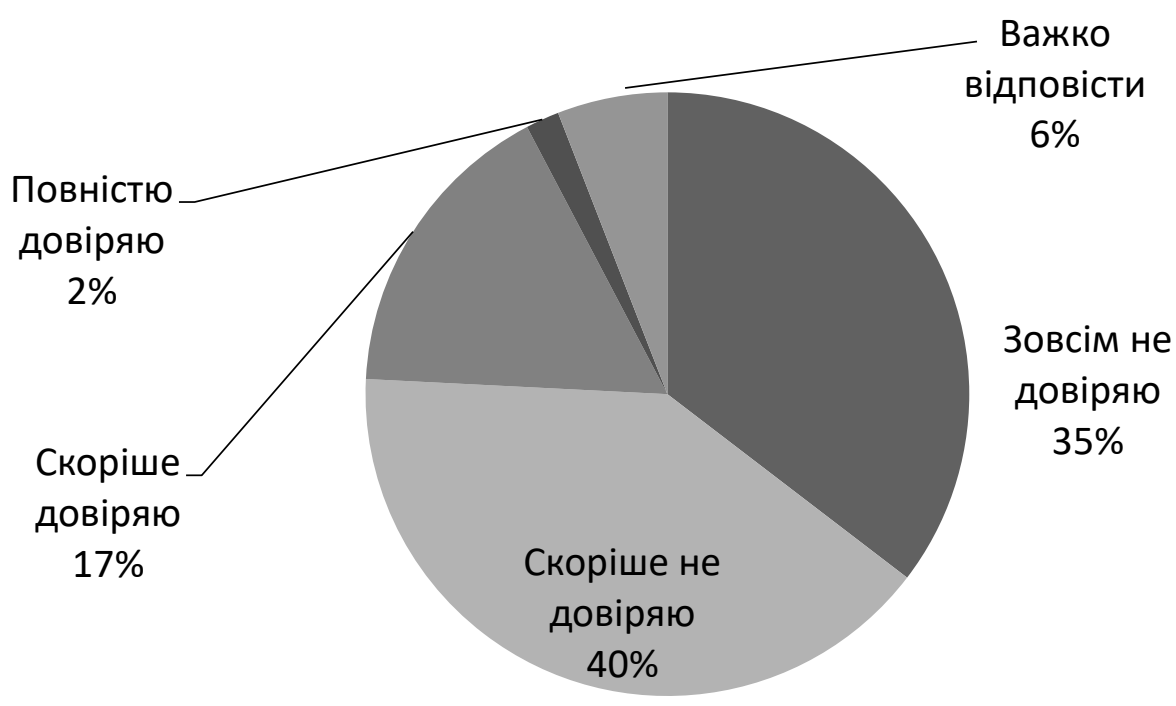

Pис. 2. Відповіді респондентів на запитання щзодо довіри Уряду України

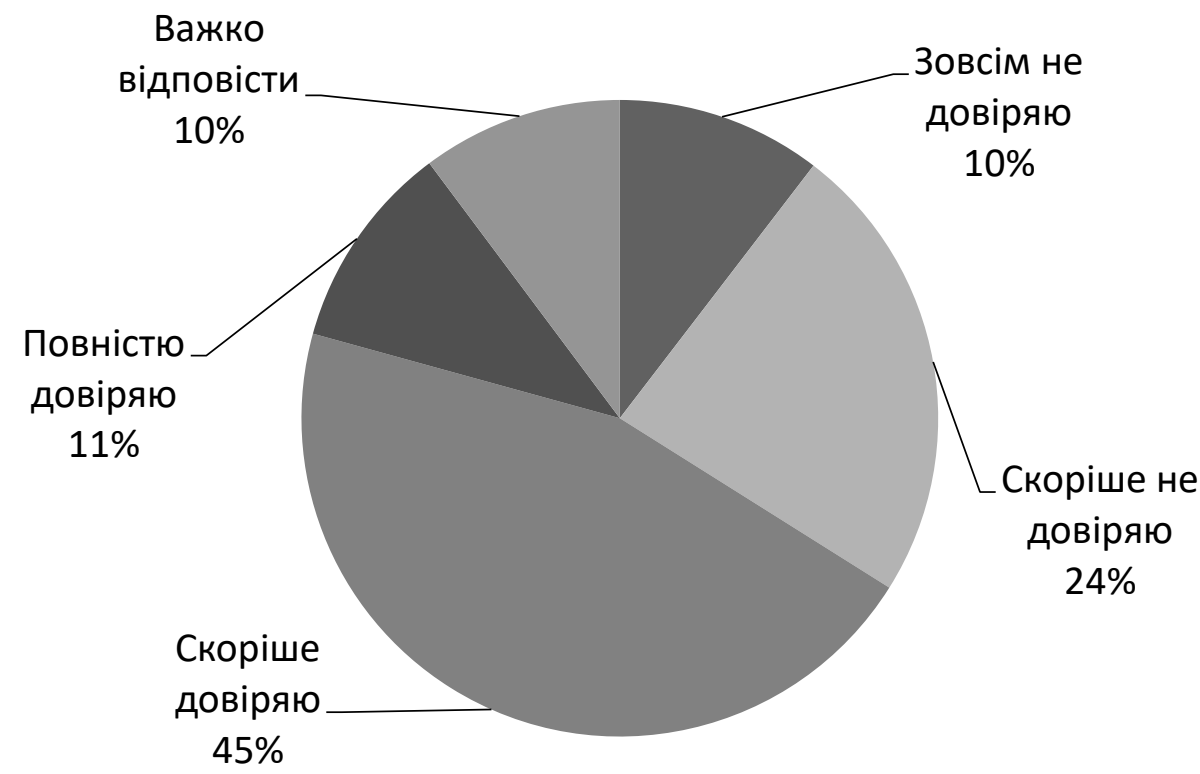

Puc. 3. Відповіді респондентів на запитання щьодо довіри міському / сільському / селищному голові

Таким чином можемо побачити, що рівень недовіри до влади в цілому досить різниться. Якщо до Президента та Уряду більшість респондентів відчуває недовіру, то до місцевого керівництва відношення більше позитивне. Також слід зазначити, що з моменту останнього дослідження владою було проведено низку заходів щодо протидії пандемії короновірусу, через що подібні показники наразі можуть значно відрізнятись.

Цікавим $є$ також відношення громадян до засобів масової інформації та громадських організацій (рис. 4, 5). 


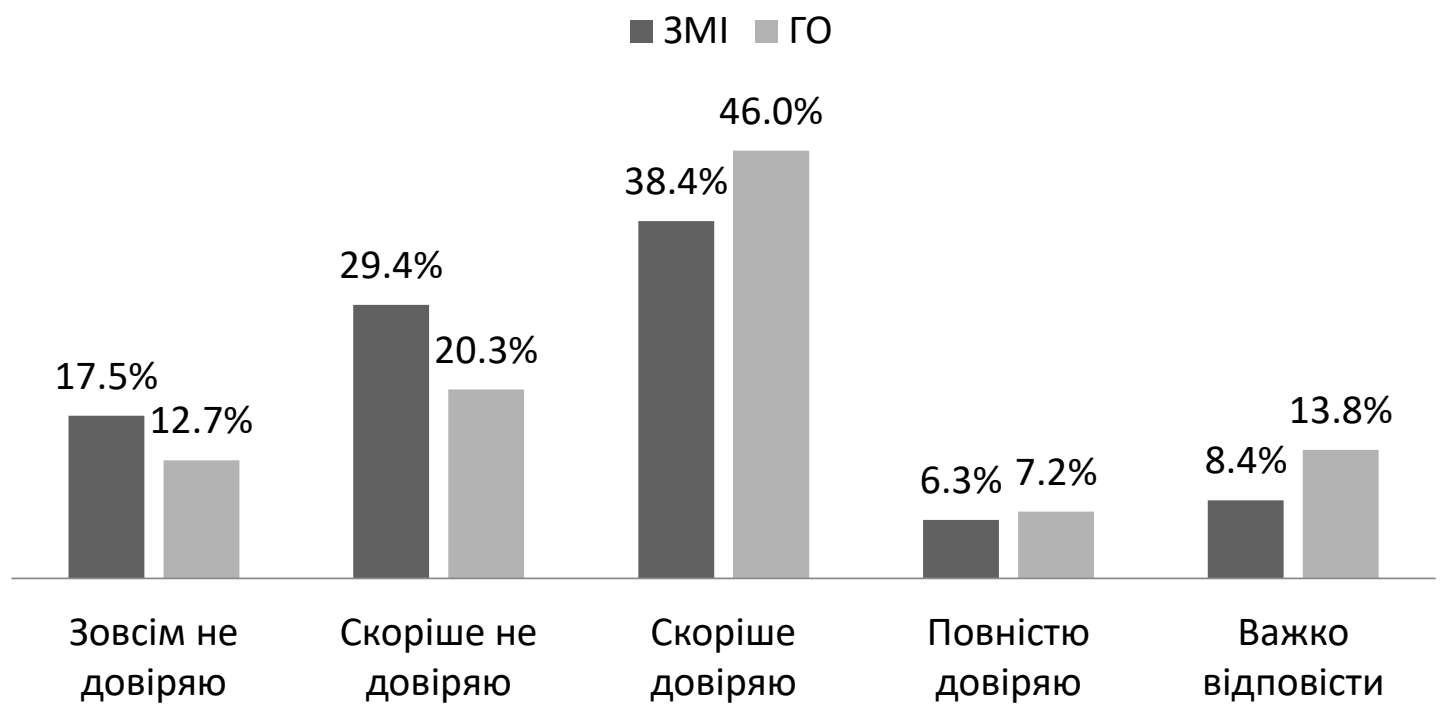

Puc. 4. Відповіді респондентів на запитання щодо довіри до ЗМI та громадських організаиій

Окрім рівня довіри, який можливо виміряти лише за допомого соціологічних опитувань та досліджень громадської думки, варто звернути увагу також і на індекс відкритості бюджету.

Так, такий індекс визначає, чи уряд надає доступ суспільству до основних бюджетних документів i чи $€$ ці документи зрозумілими, своєчасними та корисними. До переліку даних необхідних документів відносять бюджетну декларацію, проект бюджету, сам бюджет на майбутній рік, бюджет для громадян, квартальні звіти про виконання бюджету, піврічний звіт, річний звіт і звіт про аудит. Під час дослідження використовується міжнародні стандарти та експерта методологія, як розроблені Міжнародним валютним фондом, Організацією економічного співробітництва та розвитку, Міжнародною організацією вищих органів фінансового контролю (INTOSAI) [6].

Для розрахунку об’єктивної оцінки та побудови рейтингу прозорості для кожної держави використовуються бали, отримані за відповіді на 95 із 125 запитань Індексу, 30 запитань мають допоміжний характер. «Ці сумарні бали становлять єдиний незалежний i порівнювальний показник прозорості бюджету - Індекс відкритості бюджету. Оцінку Індексу відкритості бюджету ініціювало Міжнародне бюджетне партнерство, засноване 1997 року для підтримки організацій громадянського суспільства навколо світу, зацікавлених у зміцненні бюджетних інституцій, процесів та їхніх наслідків» [7, с. 59]. Так, дане оцінювання для кожної держави проводиться раз на два роки.

Щодо України, то у 2017 році Україна зайняла 39-те місце серед 115 країн світу в міжнародному рейтингу бюджетної прозорості відповідно до відповідних критеріїв. А вже у 2019 році посіла 26-е місце споміж 117 держав світу в світовому рейтингу прозорості бюджетів, тим самим піднявшись на 
13-е місце у порівнянні з попередніми показниками рейтингу у 2017 році [8]. На думку експертів, цьому сприяє виникнення таких електронних порталів, як Єдиний портал відкритих даних, діяльність системи Прозорро (щодо публічних закупівель), оновлення та опублікування публічної інформації на сайтах державних органів.

Отже, невисокий рівень довіри 3 боку суспільства до ОПВ може пояснюватися особливостями реалізації соціального діалогу в сьогоднішніх реаліях, котрий скоріш за все є ширмою для здійснення цілей, подекуди протилежних соціальному партнерству. В останні кілька років рівень довіри до ОПВ і влади в цілому зменшується. Низький рівень довіри до влади, у свою чергу, зовсім не сприяє прийняттю дієвих рішень, оскільки навіть якщо вони будуть доцільні, не сприймання їх громадськістю в кінцевому результаті впливатиме на їх практичне впровадження.

Варто зазначити, що шляхом для підвищення рівня довіри до влади, вірогідно, є налагодження діалогу та робота на засадах партнерства. Постійна співпраця, відкритість органів влади. Звітування стимулюватиме поступове формування громадської думки про основні механізми, форми і методи досягнення політичного консенсусу, соціальної солідарності та інтеграції в суспільстві. Це $є$ особливо важливим, адже у сучасних українських реаліях саме довіра, а не примус стає визначальною умовою ефективності влади, іiі здатності консолідувати суспільство у вирішенні проблем його розвитку [3].

Насамперед варто зазначити, що відкритість та прозорість ОПВ $\epsilon$ основними вимогами для ефективного функціонування державної влади, яка сформована демократичним шляхом. У разі недотримання таких вимог громадський контроль за діяльністю влади є неможливим. А закритість та непрозорість в діяльності органів влади, навпаки, сприяє іiі корупційності, через що знижується довіра до органів публічної влади в цілому [9, с. 161].

Інформаційна відкритість та прозорість ОПВ $є$ гарантією для забезпечення реального громадського контролю за іï діяльністю. Загалом громадський контроль можна визнати як базовий інструмент для забезпечення відкритості та прозорості у діяльності владних оргранів. Адже шляхом використання інструментів такого контролю (громадські слухання, опитування, запрошення представників громадськості на засідання тощо) також можливо підвищити рівень довіри до органів публічної влади як державного, так і місцевого рівня [10, с. 13$]$.

Враховуючи це, насамперед ОПВ слід у своїй діяльності більш активно залучатись до діалогу з ГО, звичайними представниками громадськості, демонструвати відкритість щодо організації незалежного громадського контролю, проведення моніторингу та аудиту. Цим самим ОПВ демонструватимуть свою повну відкритість та прозорість.

Наступні пропозиції щодо підвищення рівня довіри до ОПВ стосуються застосування положень ЗУ «Про доступ до публічної інформації», що було прийнято ще у 2011 році. Наразі фіксується низка проблем, котрі виникають під час реалізації зазначеного закону як у розпорядників публічної інформації, котрими виступають ОПВ, так і в представників суспільства, 
котрі висловили бажання скористатись таким шляхом для отримання інформації. Для вирішення даних проблем пропонується вжити наступні заходи.

По-перше, це превентивна діяльність з боку ОПВ, а саме:

1) вжиття заходів для оперативного оприлюднення публічної інформації через офіційний сайт органу чи на відповідних інформаційних pecypcax. Таким чином, громадянин, який шукає інформацію, зможе отримати іiі безперешкодно у вільному доступі і не буде змушений звертатись до розпорядника з відповідним запитом;

2) організація систематичного підвищення кваліфікації для співробітників ОПВ з метою роз'яснення положень ЗУ «Про доступ до публічної інформації» та їх практичної реалізації;

3) ретельне слідування вимогам зазначеного закону та призначення у ОПВ осіб, що відповідальні за надання своєчасних відповідей на публічні запити від громадян.

По-друге, це внесення законодавчих змін, а саме:

1) внесення змін або визнання нечинним ЗУ «Про інформацію», який $\epsilon$ морально застарілим і норми якого суперечать положенням таких законів, як «Про доступ до публічної інформації» та «Про захист персональних даних»;

2) розроблення законодавчого механізму організації громадського контролю за процесом забезпечення владними органами доступу до публічної інформації, особливо враховуючи реформу децентралізації та правовий статус об'єднаних територіальних громад;

3) створення, відповідно до рекомендацій Ради Європи, посади інформаційного омбудсмана 3 одночасним зняттям повноважень щодо контролю за додержанням права на доступ до публічної інформації, котрий сьогодні закріплено за Уповноваженим 3 прав людини, котрий не представляє каральний орган та до сфери відання якого відносяться дещо інші функції;

4) розглянути питання щодо внесення зміни до ЗУ «Про доступ до публічної інформації», а саме передбачати положення про зловживання 3 боку запитувача кількості інформаційних запитів до певного розпорядника інформації. Варто зазначити, що нещодавно у Верховній Раді було зареєстровано законопроєкт № 3660 про внесення змін до закону України «Про доступ до публічної інформації» щодо надання відповідей на запити, та 3 пропозицією про обмеження кількості запитів (не більше 5 за тиждень) та внесення змін до ч.1 ст.24 «Відповідальність за порушення законодавства про доступ до публічної інформації несуть особи, винні у вчиненні таких порушень:» п.10 «зловживання запитувачами своїм правом на доступ до публічної інформації». Проте, даний законопроект не був поки що прийнятий, у той же час у ОПВ зазначають про існування таких недобросовісних запитувачів, які фактично паралізують роботу органу влади великою кількість запитів, проте механізму впливу на них у діючому законодавстві не передбачено; 
5) збільшити санкцію за ч. 2 ст. 212-3 КУпАП, якою передбачено відповідальність за порушення ЗУ «Про доступ до публічної інформації» (на сьогодні санкція передбачає накладання штрафу на суму 425 грн., що визнається недостатнім).

Щодо підвищення рівня довіри до ОПВ, варто також зазначити про важливість взаємодії та співпраці зі ЗМІ. Для вирішення даних проблем пропонується:

1) влаштовувати діалог зі ЗМІ за допомогою делегування таких обов'язків окремій посадовій особі 3 одночасним чітким визначенням переважних напрямків у подібній взаємодії;

2) систематично надавати для ЗМІ офіційну інформацію та відповіді на актуальні питання, організовувати брифінги для надання коментарів щодо певних подій, проводити виступи на телебаченні та радіо, запрошувати журналістів на заходи, що організовані владним органом, наради, відкриті засідання тощо.

Окрім цього, на сьогодні ОПВ варто приділити увагу використанню у своїй діяльності ведення офіційних сторінок у соціальних мережах. Слід відмітити, що ОПВ, відповідаючи вимогам сучасності, повинен приділяти напрямку ведення соціальних мереж, комунікації зі ЗМІ багато уваги та ресурсів. Перш за все це необхідно для того, щоб громадяни могли отримувати справжню, не викривлену інформацію про діяльність конкретного владного органу.

3 приводу покращення ситуації з розповсюдженням інформації у соціальних мережах, пропонується вжити наступні заходи.

По-перше, за ведення соціальних мереж повинна відповідати одна посадова особа, яка б готувала та узгоджувала інформацію $з$ керівництвом ОПВ, вела сторінку у соціальні мережі, організовувала отримання зворотного зв'язку, комунікувала 3 журналістами та інститутами громадянського суспільства. Така особа (структурний підрозділ) повинна максимально оперативно реагувати на інформаційні приводи, які можуть надходити саме від соціальних мереж, через публікації, приватні повідомлення, теги у публікаціях, та отримувати за ненормовану працю відповідну оплату.

По-друге, мінімізувати випадки неоперативного викладення важливої інформації, уникати викладення фото та відео матеріалів низької якості, а також таких, котрі не відповідають змісту самої публікації чи не зовсім доречні (приміром, викладати фото масового заходу, де не забезпечено дотримання карантинних обмежень).

По-третє, удосконалювати підходи 3 добору форм подання відомостей, використовувати більше аналітичних матеріалів у візуалізованій формі (різноманітні схеми, інфографіка та інші варіанти передачі концентрованої та спрощеної для розуміння інформації).

По-четверте, використовувати соціальні мережі у ролі майданчику для реалізації просвітницької діяльності, надання громадянам консультацій, а також надання відповідей на стандартні й більш затребувані питання та 
спілкуватись з громадянами (для прикладу, на платформі Youtube можна запустити серію невеликих інформаційно-просвітницьких відеороликів щодо розгляду гострих для громадян питань, а на сторінці у соціальній мережі Facebook влаштовувати прямі ефіри та давати відповіді на питання від аудиторіi).

Також важливим фактором для підвищення рівня довіри до ОПВ $\epsilon$ звітування представників владних органів (особливо керівництва) перед суспільством. В той самий час, як свідчить практичний досвід, наразі реалізація практики звітування перед суспільством, має низку недоліків як у законодавчому забезпеченні, так і у його практичній реалізації. Для усунення даних проблем пропонуються наступні рішення:

1) внести зміни до законодавства (а саме до ЗУ «Про місцеве самоврядування в Україні») та чітко встановити необхідність звітування, види та кількість подібного звітування, а також встановити вимоги до такого звіту (він, по-перше, має бути відритим, а по-друге, доступним для громадян);

2) визначити чіткі нормативні критерії щодо встановлення сутності звіту, особливо це стосується виконання передвиборчих обіцянок та програмних положень, прийняття суспільно важливих рішень та спілкування 3 представниками ГО, окремими виборцями або виконання стратегій та програм як загальнодержавного, так і місцевого рівня;

3) передбачити функціонування механізму звітування ОПВ за ініціативи представників громадських організацій та спонукати до прояву подібної ініціативи від громадян (для прикладу, шляхом подання електронних петицій або громадських ініціатив) [11].

3 приводу визначеної проблематики у напрямку звітування про використання публічних коштів, то іiі можливо вирішити шляхом організації заходів 3 підготовки спеціалістів, котрі мають наповнювати офіційний сайт владного органу. Окрім цього, потрібно усунути законодавчу прогалину відносно відповідальності за порушення норм, пов'язаних із розміщенням даних на порталі C-Data, та викласти ч. 1 ст. 212-3 КУпАП у такій редакції:

«Неоприлюднення інформації, обов'язкове оприлюднення якої передбачено законами України «Про доступ до публічної інформації», «Про оцінку впливу на довкілля», «Про особливості доступу до інформації у сферах постачання електричної енергії, природного газу, теплопостачання, централізованого постачання гарячої води, централізованого питного водопостачання та водовідведення», «Про доступ до архівів репресивних органів комуністичного тоталітарного режиму 1917-1991 років», «Про запобігання корупції», а також оприлюднення недостовірної, неточної чи неповної інформації; несвоєчасне оприлюднення інформації відповідно до закону України «Про відкритість використання публічних коштів» - тягне за собою накладення штрафу на посадових осіб від двадцяти п’яти до п’ятдесяти неоподатковуваних мінімумів доходів громадян» [12].

Разом 3 вище наведеним пропонується дослідити проблему щодо посилення санкції за вчинення подібного роду порушень. 
Висновки. 3 приводу підвищення рівня довіри до ОПВ шляхом взаємодії та залучення до управлінської діяльності представників ГО, то, вочевидь, ОПВ потрібно знаходити дієві механізми та реальні шляхи взаємодії з ГО з метою вирішення суспільно значущих питань та виявляти готовність надати представникам громадськості можливостей здійснювати контроль за своєю діяльністю з метою збільшення прозорості та відкритості владних органів.

По-перше, для налагодження ефективної взаємодії ГО та ОПВ необхідно, перш за все, звернути увагу на інформаційну відкритість органу та на налагодженість системного інформаційного обміну останніх із інститутами суспільства. Слід наголошувати на тому, що взаємодія зі ЗМІ та висвітлення діяльності ОПВ у соціальних мережах $є$ показниками відкритості органу, що, у свою чергу може спонукати ГО до співпраці, активної участь у прийняті рішень органу, адже у нього вже $є$ певний рішень довіри та відкритості.

По-друге, необхідно приділити увагу правовій стороні даного питання. Наприклад, в місцевих органах влади можна створити громадську раду, консультативні-дорадчі органи, молодіжні ради, однак створення подібних інституцій має забезпечуватись у тому числі й належним правовим супроводом. Так, до подібних дорадчих органів бажано має бути наявність відкритих конкурсів, а самі вимоги до представників ГО мають бути чітко визначеними. Сама ж діяльність такого органу передбачає регламентацію через відповідні нормативні документи, що будуть затверджені в установленому законом порядку.

По-третє, під час налагодження взаємодії з ГО необхідно враховувати, що на сьогодні одним із завдань громадянського суспільства $\epsilon$ також недопущення корупції, викриття корупційних зловживань 3 боку представників того чи іншого органу. Через це ОПВ повинен особливо звертати увагу на співпрацю з ГО даного напрямку, адже така відкритість буде ще більше сприяти підвищенню рівня відкритості органу до суспільства.

По-четверте, під час налагодження співпраці ОПВ варто звертати увагу на цілях та завданнях ГО відповідно до іiі реального статуту, а також врахування того, інтереси якої самк соціальної групи вона представляє. Варто звернути увагу, що через діяльності ГО можуть бути виявлені різноманітні інтереси громадян та їх суспільних груп, на цій основі формуються позиції щодо того чи іншого питання суспільного життя i реалізується конструктивна форма взаємодії суспільства 3 владою. Тому доцільно висловити думку, що даний аспект повинен бути врахований, $\mathrm{i}$, наприклад, представника Всеукраїнського ГО «Союз осіб з інвалідністю» варто включати до місцевого комітету доступності, або до громадської ради при органі соціального захисту населення. Так співпраця ГО та ОПВ буде найбільш ефективною.

Отже, у випадку налагодження діалогового механізму та налагодження співпраці владного органу з ГО або ЗМІ, виконання вимог законодавства 
щодо забезпечення відкритості та доступності інформації, організації звітування про свою діяльність, держава в цілому та зокрема ОПВ можуть отримати доволі значний рівень довіри від громадськості, що згодом може допомогти у проведенні прогресивних та практично спрямованих реформ, збільшити політичну участь активної частки громадян у процесі прийняття суспільно значущих рішень.

\section{Лimepamypa:}

1. Серьогін С. М., Письменний І. В. Відновлення довіри до органів публічної влади як умова успішності реформ в Україні // Аспекти публічного управління. № 4, 2015, с. 62-66.

2. Кучабський О. Г., Погорєлий С. С. Довіра до органів публічної влади як ключовий фактор ефективності системи державного управління // Публічне управління: теорія та практика. Вип. 1, 2013, с. 103-108.

3. Кучабський О. Г., Погорєлий С. С. Довіра до органів публічної влади як показник ефективності влади // Молодий вчений. № 1, 2013, с. 87-91.

4. Родченко Л. М. Система принципів взаємовідносин органів державної влади 3 інституціями громадянського суспільства в Україні // Наукові записки Інституту законодавства Верховної Ради України. № 6, 2018, с. 154-158.

5. Центр Разумкова. https://razumkov.org.ua.

6. INTOSAI - Міжнародна організація вищих органів аудиту. https:// www.intosai.org/ru/.

7. Куценко Т. Ф. Сучасний інструментарій забезпечення прозорості місцевих бюджетів в Україні: оглядовий аналіз // Економіка та держава. № 10, 2019, с. 58-64.

8. Україна піднялася на 26 місце в міжнародному рейтингу бюджетної прозорості: сайт УНIAH. https://www.unian.ua/economics/finance/reyting-byudzhetnoji-prozorostiukrajina-pidnyalasya-na-26-misce-novini-ukrajina-10980155.html.

9. Куспляк I. Прозорість та відкритість влади: від концепту «прозорого міста» до порталу відкритих даних // Теоретичні та прикладні питання державотворення. Вип. 16, 2015 , с. $159-171$.

10. Грибко О. В. Громадський контроль як базовий інструмент забезпечення прозорості та відкритості системи публічного управління // Державне будівництво. № 2, 2017, c. 13-15.

11. Тимофєєв С. Загальні засади забезпечення відкритості та прозорості органів публічної влади в Україні // Публічне управління та регіональний розвиток. №11, 2021, с. 251-279.

12. Висновок на проект Закону України «Про внесення змін до Кодексу України про адміністративні правопорушення щодо забезпечення прозорості та відкритості діяльності місцевих рад та інших суб'єктів владних повноважень». https://itd.rada.gov.ua/billInfo/ Bills/informLetterDocFile?fileId=559631.

\section{References:}

1. Ser'ohin, S. M., Pys'mennyj, I. V. (2015) Vidnovlennia doviry do orhaniv publichnoi vlady iak umova uspishnosti reform v Ukraini [Restoration of trust in public authorities as a condition for the success of reforms in Ukraine]. Aspekty publichnoho upravlinnia-Aspects of public administration, 4, 62-66 [in Ukrainian].

2. Kuchabs'kyj, O. H., Pohorielyj, S. S. (2013) Dovira do orhaniv publichnoi vlady iak kliuchovyj faktor efektyvnosti systemy derzhavnoho upravlinnia [Trust in public authorities as a key factor in the effectiveness of public administration]. Publichne upravlinnia: teoriia ta praktyka - Public administration: theory and practice, 1, 103-108 [in Ukrainian]. 
3. Kuchabs'kyj, O. H., Pohorielyj, S. S. (2013) Dovira do orhaniv publichnoi vlady iak pokaznyk efektyvnosti vlady [Trust in public authorities as an indicator of government efficiency]. Molodyj vchenyj - Young Scientist, 1, 87-91 [in Ukrainian].

4. Rodchenko, L. M. (2018) Systema pryntsypiv vzaiemovidnosyn orhaniv derzhavnoi vlady z instytutsiiamy hromadians'koho suspil'stva $\mathrm{v}$ Ukraini [System of principles of relations of public authorities with civil society institutions in Ukraine]. Naukovi zapysky Instytutu zakonodavstva Verkhovnoi Rady Ukrainy - Scientific notes of the Institute of Legislation of the Verkhovna Rada of Ukraine, 6, 154-158 [in Ukrainian].

5. The Razumkov Centre. https://razumkov.org.ua.

6. INTOSAI - International Organization of Supreme Audit Institutions. https://www.intosai.org

7. Kutsenko, T. F. (2019) Suchasnyj instrumentarij zabezpechennia prozorosti mistsevykh biudzhetiv v Ukraini: ohliadovyj analiz [Modern tools for ensuring the transparency of local budgets in Ukraine: a review analysis]. Ekonomika ta derzhava - Economy and state, 10, 58-64 [in Ukrainian].

8. Ukraine rose to 26th place in the international ranking of budget transparency: UNIAN website. https://www.unian.ua/economics/finance/reyting-byudzhetnoji-prozorosti-ukrajinapidnyalasya-na-26-misce-novini-ukrajina-10980155.html. [in Ukrainian].

9. Kuspliak, I. (2015) Prozorist' ta vidkrytist' vlady: vid kontseptu «prozoroho mista» do portalu vidkrytykh danykh [Transparency and openness of government: from the concept of "transparent city" to the open data portal]. Teoretychni ta prykladni pytannia derzhavotvorennia - Theoretical and applied issues of state formation, 16, 159-171 [in Ukrainian].

10. Hrybko, O. V. (2017) Hromads'kyj kontrol' iak bazovyj instrument zabezpechennia prozorosti ta vidkrytosti systemy publichnoho upravlinnia [Public control as a basic tool for ensuring transparency and openness of the public administration system]. Derzhavne budivnytstvo - State building, 2, 13-15 [in Ukrainian].

11. Tymofieiev, S. (2021) Zahal'ni zasady zabezpechennia vidkrytosti ta prozorosti orhaniv publichnoi vlady $\mathrm{v}$ Ukraini [General principles for ensuring the openness and transparency of public authorities in Ukraine]. Publichne upravlinnia ta rehional'nyj rozvytok - Public administration and regional development, 11, 251-279 [in Ukrainian].

12. Vysnovok na proekt Zakonu Ukrainy "Pro vnesennia zmin do Kodeksu Ukrainy pro administratyvni pravoporushennia schodo zabezpechennia prozorosti ta vidkrytosti diial'nosti mistsevykh rad ta inshykh sub'iektiv vladnykh povnovazhen'”. Retrieved from https://itd.rada.gov.ua/billInfo/Bills/informLetterDocFile?fileId=559631 [in Ukrainian]. 